Jurnal Penyuluhan Perikanan dan Kelautan, 11(1): Halaman: 25-34

\title{
Peran Kearifan Lokal Suku Bajo dalam Mendukung Pengelolaan Kawasan Konservasi di Kabupaten Wakatobi
}

\author{
[The Role Of Bajonese Local Wisdom in Supporting The Management Conservation Area \\ on Wakatobi Regency] \\ Esti Hasrawaty ${ }^{\bowtie}$, Pigoselpi Anas, Sugeng Hari Wisudo \\ Sekolah Tinggi Perikanan \\ Jalan AUP Nomor 1 Pasar Minggu, Jakarta Selatan
}

Diterima: 30 Januari 2017; Disetujui: 30 Maret 2017

\begin{abstract}
Abstrak
Penelitian ini bertujuan menganalisis kondisi ekosistem perairan di Taman Nasional Laut Wakatobi,menganalisis efektivitas implementasi kearifan lokal nelayan Suku Bajo dan perannya dalam pengelolaan sumberdaya perikanan sebagai upaya mendukung pengelolaan kawasan konservasi.Penelitian ini dilaksanakan di Kawasan Konservasi Kabupaten Wakatobi diwakili oleh Kecamatan Wangi-Wangi Selatan dan Kecamatan Kaledupa mulai dari bulan Januari-Maret 2016. Lokasi dipilih secara sengaja (purposive). Teknik pengumpulan data dilakukan dengan wawancara, observasi dan Focus Groups Discustion (FGD). Pengamatan persentase tutupan karang di lokasi pengamatan dilakukan dengan metode transek garis segmen atau Point Intercept Transec (PIT). Pengamatan lamun dilakukan secara langsung pada masing-masing transek pada stasiunnya, kemudian dilakukan identifikasi dan pencatatan terhadap jenis lamun yang ditemukan.Implementasi kearifan lokal nelayan Suku Bajo dapat dikatakan efektif pada beberapa stasiun yang ditujukan dengan kondisi karang yang masih terjaga. Kearifan Lokal Suku Bajo antara lain: tuba dikatutuang larangan penangkapan dalam jumlah besar di area ini dan penggunaan alat tangkap yang tidak ramah lingkungan. Parika merupakan sistem kelembagaan bertindak sebagai penentu waktu penangkapan dan tempat penangkapan.
\end{abstract}

Kata kunci: Kearifan lokal, Lamun, Terumbu karang, Suku Bajo.

\begin{abstract}
The intention of the research is analizing ecosystem condition in Wakatobi Marine National Park, analizing the effectivity of implementation Bajo ethnic local wisdom and its role for management resources as an effort to support management conservation area. This research done during Januari to March 2016 at Wakatobi Conservation Area, represented by Wangi-Wangi Selatan district and Kaledupa district. The location selected by purposively.Method of data collecting in this research is using interview, observation and Focus Groups Discustion(FGD). Coral coverage percentation observation used Point Intercept Transect (PIT) method. Seagrass observation used direct observation in every transect of all stations, then identification and recording seagrass type that found. Bajo ethnic local wisdom implementation effective in station who have coral coverage keep in good condition. Bajo ethnic local wisdom consist of: tuba didikatutuang (prohibiton high amountcatch in this area and non environmental friendly fishing gear) and parika (institutional system as catching time and place determination).
\end{abstract}

Keywords: Local Wisdom, Seagrass, Coral Reef, Bajonese.

$\triangle$ Penulis korespondensi

Alamat surel: hesti@gmail.com 


\section{PENDAHULUAN}

Pada tahun 1996, Taman Nasional Wakatobi (TNW) ditunjuk oleh pemerintah melalui keputusan Menteri Kehutanan No.393/KPTSS-VI/1996 tanggal 30 Juli 1996 dan ditetapkan melalui Keputusan Menteri Kehutanan Nomor 7651/Kpts-II/2002 tanggal 19 Agustus 2002 yang meliputi kawasan seluas $\pm 1,39$ juta hektar. Kawasan ini ditetapkan sebagai Taman Nasional untuk menjaga pelestarian keanekaragaman hayati (biodiversity conservation) sebagai perwakilan ekosistem wilayah ekologi perairan laut Banda-Flores (Banda Flores Marine Eco-region) (Kemenhut, 2012).

Walaupun Wakatobi telah di tetapkan sebagai Taman Nasional, ancaman yang datang dari dalam maupun luar tidak serta merta berhenti. Beberapa isu yang mengancam keberadaan kawasan konservasi di perairan Wakatobi antara lain adalah: (1) penangkapan ikan dengan menggunakan bahan peledak, potassium dan penangkapan ikan berlebih; (2) peningkatan kegiatan pembangunan dan jumlah penduduk akan berdampak dengan peningkatan kebutuhan pemanfaatan sumberdaya alam di kawasan Taman Nasional Laut Wakatobi seperti pasir, batu karang/batu gunung, biotal laut dll; (3) peningkatan jumlah kunjungan wisatawan, aktivitas perdagangan, yang datang ke Wakatobi tanpa perencanaan yang baik dapat merusak sumberdaya alam dan suatu tatanan sosial kemasyarakatan. Suku Bajo sebagai komunitas yang tidak bisa dipisahkan dengan laut, memiliki tradisi yang unik dan amat kaya dalam hubungannnya dengan laut. Kekayaan kebudayaan Suku Bajo ini berbeda-beda diberbagai tempat dimana komunitas Suku Bajo berada, sesuai dengan faktor teritorial dan geneologis mereka. Tapi ada satu kesamaan, yaitu Suku bangsa ini memiliki kearifan lingkungan sebagai hasil dari suatu proses adaptasi terhadap perubahan lingkungan yang terjadi secara turun temurun. Dari proses yang berlangsung puluhan tahun, bahkan ratusan tahun itu, akhirnya membentuk semacam mekanisme pemecahan masalah.

Kearifan lokal dan pengetahuan lokal yang dimiliki oleh suatu masyarakat diperoleh melalui proses yang panjang. Keberadaanya merupakan hasil adaptasi melalui proses belajar sosial terhadap kondisi dan dinamika lingkungannya, baik lingkungan alam maupun lingkungan sosial. Dengan demikian, kearifan dan pengetahuan lokal sudah teruji dan 
selalu mengalami kontekstualisasi, sejalan dengan perkembangan dan perubahan yang terjadi. Sebagai konsekuensinya, kearifan dan pengetahuan lokal bukan sesuatu yang bersifat statis, melainkan selalu berkembang secara komulatif, sejalan dengan perkembangan masyarakatnya.

Berdasarkan uraian pada latar belakang diatas, maka masalah penelitian ini dapat dirumuskan sebgai berikut: Bagaimana peran kearifan lokal yang terdapat pada Suku Bajo dalam kondisi pengelolaan kawasan konservasi?

Tujuan yang ingin dicapai melalui penelitian ini adalah: Menganalisis kondisi Ekosistem Perairan di Taman Nasional Laut Wakatobi melalui repsentatif tutupan lamun dan tutupan karang;

Penelitian mengenai peran kearifan lokal Suku Bajo dalam mendukung pengelolaan Kawasan Konservasi Laut di Kabupaten Wakatobi dilatar belakangi oleh kebiasaan menangkap ikan dengan menggunakan alat dan cara tradisional yang telah menjadi warisan turun temurun di masyarakat Wakatobi.

Pengelolaan suatu areal kawasan konservasi di Kabupaten Wakatobi terlebih dahulu dimulai dengan langkah-langkah indentifikasi jenisjenis kearifan lokal yang digunakan oleh nelayan Suku Bajo dalam pemanfaatan sumberdaya perikanan.

\section{BAHAN DAN METODE}

Penelitian ini dilaksanakan di Kawasan Taman Nasional Laut Wakatobi diwakili oleh Kecamatan Wangi-Wangi Selatan dan Kecamatan Kaledupa mulai dari bulan JanuariMaret 2016.

Penentuan responden dilakukan dengan sengaja (purposive sampling). Responden adalah anggota masyarakat suku Bajo yang telah dewasa yang melakukan aktivitas pengelolaan perikanan secara tradisional dan masih memegang teguh nilai-nilai kearifan lokal.

Teknik pengumpulan data dilakukan dengan beberapa cara : observasi, Wawancara dan Focus Group Discussion/FGD.

\section{HASIL DAN PEMBAHASAN}

\section{Kearifan Lokal Suku Bajo}

Kearifan lokal merupakan gagasan masyarakat setempat yang bernilai baik, berupa pandangan hidup, tata nilai, adat istiadat norma, biasanya bersimbolisasi mitos dan ritual (Sartini, 2009). Corak tradisi dan budaya melaut 
Suku Bajo yang berkaitan dengan laut dan fungsi laut sebagai tempat kehidupan, menggambarkan bahwa tata nilai, adat istiadat ataupun norma yang ada di dalamnya merupakan upaya bagi Suku Bajo dalam melindungi suatu kawasan.

\section{Tubba Dikatutuang}

Masyarakat Suku Bajo Desa menggantungkan hidupnya di laut. Masyarakat Suku Bajo sangat percaya jika terumbu karang rusak maka tidak akan ada ikan lagi. Oleh karena itu pada tahun 2006 Suku Bajo membuat kesepakatan bersama dengan tujuan dalam melindungi kawasan konservasi yaitu Tubba dikatutuang. Sebagaimana yang dijelaskan oleh salah satu Responden yang bernama Bapak Jabira selaku mantan kepala dusun dan tokoh masyarakat di desa Sampela: “Tubba dikatutuang memiliki arti kata "karang yang disayang”. Orang tua terdahulu sudah memberikan pesan supaya tempat yang disakralkan harus di jaga dengan baik karena sumberdaya ikan yang ada di tempat tersebut sangat melimpah. Jadi menurut mereka ada nilai kepercayaan Suku Bajo yang selaras dengan pengelolaan wilayah konservasi antara lain: (1) dilarang menangkap ikan di daerah konservasi dalam jumlah yang berlebihan; (2) dilarang menangkap ikan yang sedang bertelur

pelarangan segala bentuk aktivitas penangkapan di daerah ini; (4) pelarangan pembuangan jangkar karena akan merusak karang di lokasi Tuba; (5) pelarangan penangkapan ikan yang dilindungi. Hal ini dilakukan sebagai usaha untuk menjaga keseimbangan populasi dan regeneraasi spesies. Di tempat ini ada larangan-larangan yang telah disepekati untuk tidak mengelola hasil perikanan.

Tuba dikatutuang termasuk di dalam lokasi daerah perlindungan laut. Daerah ini berada tepat di hadapan pulau Hoga dan di dekat pemukiman warga Desa dengan radius panjang 400 m. Dengan kondisi terumbu karang dan ikan yang masih melimpah. Kawasan atau areal ini juga merupakan daerah perlindungan laut, dimana data tahun 2009 coremap menyatakan bahawa persentase tutupan karang di DPL berkategori bagus (62\%) tutupan karang hidup yang terdiri dari Acropora 16\%, Non Acropora $46 \%$, Soft Coral $14 \%$ dan Rubble 5\%.

Sanksi jika nelayan melakukan penangkapan di area tuba adalah sebagai berikut: (1) pelanggaran I (ringan): masih berupa teguran dan sosialisasi; (2) pelanggaran II (sedang): apabila tertangkap lagi dan 
dikembalikan di Desa; (3) pelanggaran

III (berat): denda berupa uang sebesar Rp. 2.000.000 untuk diserahkan di Kecamatan.

\section{Sistem Parika}

Parikaadalah suatu sistem kelembagaan yang sudah ada dalam kelompok nelayan Suku Bajo. Seorang Parika adalah seseorang yang memiliki kemampuan mistik yang lebih tinggi dibandingkan yang lain. Parikajuga dianggap sebagai penjaga, pengawal dan penasehat dalam menentukan daerah penangkapan dan waktu penangkapan ikan. Sistem parikaini berlangsung secara turun temurun di Suku Bajo dan sampai sekarang masih terus dilaksanakan. Penunjukkan Parika didasarkan atas: keturunan dan yang terpenting adalah kedewasaan diri dari nelayan itu sendiri dan juga memiliki kemampuan dalam memimpin nelayan yang lain. Menurut Sartini (2013), dalam tradisi Suku Bajo ada beberapa tradisi yang bernilai konservasi melalui parika,sebagai ketua komunitas yang atas kesepakatan bersama memberi batasan penangkapan dan memberikan ruang bagi ikan untuk bertelur dan beranak. Parikabagi anggota kelompok adalah henangkara artinya seseorang yang diikuti atau (panutan) karena memiliki suatu kemampuan dalam menentukan waktu pemasangan alat ataupun ukuran alat tangkap yang akan digunakan (Hanan, 2010).

Sistem kerjanya Parika sebagai ketua yang akan memutuskan waktu penangkapan, tempat penangkapan dan sistem pembagian hasil. Sistem kerjanya Parika sebagai ketua memimpin ke daerah penangkapan ikan setelah areal tempat penangkapan ditentukan, Parikamenata jaring membentuk lingkaran dan panuba bertugas menggiring ikan ke arah jaring dengan memumukul permukaan air laut dengan tongkat bambu setelah itu panuba masuk ke dalam air laut dan melakukan kegiatan memanah ikan. Sistem pembagian hasil tangkapan Parikasebagai pemilik jaring mendapat dua bagian, dua orang sehe (teman) mendapat masing-masing satu bagian dan apa yang didapatkan panuba dari hasil memanah menjadi milik dia sendiri.Dalam sistem Parika apabila ada yang melakukan pelanggaran maka akan dilakukan teguran kepada nelayan yang melanggar tersebut.

\section{Situs Keramat Suku Bajo}

Situs keramat alami adalah konservasi lokal yang digagas dan dikembangkan oleh masyarakat lokal dalam rangka untuk melestarikan lingkungan (Royani, 2012). Perlakuan 
Kearifan Lokal Suku Bajo dalam mendukung Pengelolaan

Kawasan Konservasi di Kabupaten Wakatobi

masyarakat Suku Bajo terhadap

kawasan konservasi yaitu dengan pengkramatan situs alami. Situs yang dikeramatkan ini terjadi secara turun temurun dan masih berlangsung sampai dengan saat ini/sekarang. Kepatuhan masyarakat kepada situs keramat menjadi bagian penting dari konservasi kawasan, meskipun dari aspek luas tidak begitu besar, tetapi dampaknya sangat penting dalam menjamin konservasi keanekaragaman hayati dan pelestarian budaya (Hanan, 2010 dalam Soedjito, 2001).

Situs keramat alami, pada umumnya dipelihara dan didukung oleh sekelompok masyarakat yang berada disekitar situs keramat. Dimana keberadaannya dapat memunculkan kearifan lokal masyarakat secara khusus (Sartini et al., 2012). Situs keramat alami merupakan bagian dan cara yang efektif untuk melakukan konservasi lingkungan.

\section{Karang Tapotong (Karang Pakitta)}

Suku Bajo sebagai suku manusia laut yang memiliki hubungan yang sangat erat dengan laut sangat menghormati laut dalam pengelolaan perikanan hal ini ditandai dengan Sebelum melakukan aktivitas di daerah ini terlebih dahulu nelayan Suku Bajo melakukan ritual izin terhadap laut.
Setelah sampai di lokasi yang dianggap sakral oleh Suku Bajo, nelayan memohon izin kepada penghuni laut dengan cara sebagai berikut: mencelup kacamata air atau oleh Suku Bajo biasa disebut "cermin" ke dalam air laut, setelah itu mencuci muka dengan air laut sebanyak tiga kali dan mencelup pergelangan tangan ke dalam air dan berucap "kami datang sebagai saudara bukan sebagai Musuh”. Setelah ritual dilaksanakan maka nelayan boleh melakukan aktivitas di tempat ini. Menurut Saad (2009) keteguhan orang Bajo dalam memegang nilai-nilai dan tradisi adat leluhur terutama dalam hal yang berkaitan dengan penangkapan ikan, sesungguhnya merupakan modal sosial yang sangat penting dalam upaya memasyarakatkan gerakan konservasi. Karena dalam banyak hal sebagaimana yang sudah diutarakan sebelumnya, telah terbentuk suatu mekanisme budaya untuk ikut menjaga keseimbangan sumberdaya alam. Meski faktor pendorongnya adalah ketakutan pada Mbo, bukan atas alasan konservasi. Namun demikian, apapun alasanya, sungguh suatu potensi dasar untuk dikembangkan menjadi suatu sikap hidup yang ramah lingkungan yaitu melalui pengkeramatan suatu tempat. Masyarakat suku Bajo tidak akan berani 
menangkap ikan dikawasan ini karena adanya faktor keyakinan.

Dilokasi ini juga rutin diadakan acara upacara ritual muduai arak. Hal ini dilakukan jika akan memulai penangkapan ikan, hasil tangkapan sedikit, untuk mengobati penyakit, dan jika Suku Bajo Sama Bahari ingin merantau ke daerah orang. Ritual maduai arak ini dilakukan sebagai bentuk penghargaan terhadap "Mbo Madilao”. Selain itu juga nelayan Suku Bajo percaya bahwa "Mbo Madilao" akan menjaga mereka dari penyakit dan bencana di laut. Atas kepercayaan tersebut, maka mereka akan selalu melakukan ritual Maduai arak untuk menghargai keberadaan kepercayaan "Mbo Madilao". Kepercayaan ini sangat bermanfaat bagi konservasi laut sehingga keanekaragaman hayati di laut bisa terjaga, terutama kekayaan sumberdaya ikan dan terumbu karang. Semangat melindungi alam menjadi bagian dari hidup masyrakat sekitar karena dibarengi dengan kepercayaan dan kekuatan spiritual yang berkaitan dengan laut.

\section{Lua Angalo}

Bagi masyarakat Suku Bajo Mola dan suku Bajo lainnya yang ada di Wakatobi, laut bagi mereka adalah media Tuhan dalam memberikan semua keberkahan. Laut bukan hanya sebagai tempat tinggal juga sebagai tempat mencari makan dan sebagai tempat bagi mereka menemukan kesenangan dan melepaskan kesedihan. Oleh karena itu wajib bagi mereka untuk melakukan ritual "maduai pinah" di daerah Karang Kaledupa dimana situs keramat itu dinamakan lua angalo. Hal ini dilakukan untuk menghormati mpu madilaoatau nenek moyang orang Bajo. Lua angaloterletak disekitar pos Jagawana dan diantara lampu mercusuar di tempat ini nelayan Suku Bajo meyakini bahwa tempat ini ada penghuninya yaitu Gurita.

Semua lokasi situs sakral Suku Bajo merupakan bagian dari daerah perlindungan laut yang berarti terbuka untuk segala bentuk penggunaan tradisional ramah lingkungan untuk mengambil hasil laut tetapi tidak boleh mengeluarkan kata-kata yang tidak sopan, dan di situs keramat ini tidak boleh membuang cabe, asam, bahkan tidak boleh mencuci alat masak terutama belanga di lokasi ini, karena akan membawa kemarahan bagi Mbo Janggo. Hasil wawancara dengan Bapak Ndau (54): “Orang tua kami dulu mengatakan bahwa banyak dari kami memiliki kembaran dengan gurita termasuk anak saya. Apabila anak saya 
sakit dan sudah melakukan banyak pengobatan tapi tidak bisa sembuh, maka kami harus melakukan upacara Maduai pinah di lokasi ini. Apabila si anak memiliki kembaran dengan gurita maka si anak dan keluarganya tidak boleh memakan gurita kalau kami tidak mengikuti aturan ini maka anak kami akan terkena penyakit.

Keyakinan etnik Bajo bahwa ritual duata berkaitan dengan pemujaan terhadap penguasa laut dan saudara kembaran (kaka) yang dipercayai bahwa setiap kelahiran anak memiliki kembaran di laut (kaka) berupa gurita dan buaya. Sehingga jika salah satu diantara mereka ada yang sedang sakit, itu berarti sebagian semangat hidupnya (sumanga) telah diambil oleh saudara kembarnya ke laut dan sebagian lagi diambil oleh dewata(Tuhan Yang Maha Esa) dan dibawah ke langit ke tujuh (Basri, 2014).

Orang Bajo memiliki keyakinan bahwa ada hukum alam yang akan langsung memberikan sanksi kepada nelayan apabila akan melakukan pelanggaran. Suku Bajo memiliki keyakinan yang sangat kuat apabila melakukan pelanggaran di laut maka kapal mereka akan tenggelam di laut. Tersambar petir, hujan yang akan berlangsung secara terus menerus bahkan badai pun akan menghantam pemukiman masyarakat Suku Bajo, dan kapal akan tenggelam di laut. Menurut Saad (2009) manusia Bajo diajarkan secara turun temurun dan para pendahulunya untuk memelihara alam, dengan tidak memasuki daerah-daerah yang dilarang dan tidak melakukan suatu perbuatan yang bisa menimbulkan kemarahan alam.

Oleh karena itu, situs keramat alami yang dimiliki oleh Suku Bajo, terhindar dari kerusakan yang diakibatkan oleh penggunaan alat tangkap yang destructif, dan pada akhirnya memiliki fungsi yang sangat penting bagi tujuan konservasi, yaitu konservasi karang sebagai tempat hidup berbagai jenis ikan dan fungsi sosial budaya untuk kepentingan Suku Bajo itu sendiri dalam rangka melestarikan budaya dan tradisi yang berkembang sejak zaman nenek moyang terdahulu bahkan sampai sekarang. Menurut Sartini et al.(2012), kawasan larangan atau sering juga disebut situs sakral alami sebenarnya tidak hanya terdapat di Indonesia, akan tetapi negara Asia, Afrika dan bahkan Eropa memiliki situs keramat alami dan mereka percaya bahwa tempat-tempat sakral tersebut mempunyai kekuatan supranatural dan orang di luar Negeri juga mengadakan 
ritual sebagai bentuk penghargaan terhadap alam yang berorientasi pada konservasi lingkungan.

Bagi masyarakat Suku Bajo yang tersebar di Kabupaten Wakatobi, laut bagi mereka adalah berkah alam sebagai modal untuk kepentingan sosial. Masyarakat Suku Bajo memiliki kearifan lokal yang mengakar sejak zaman leluhur. Akan tetapi nilai-nilai arif tersebut sedikit mengalami pergeseran terutama Suku Bajo yang mendiami Kecamatan Wangi-Wangi Selatan. Hal ini sesuai dengan pendapatan Baharudin (2011), perubahan nilai tradisional Suku Bajo yang terdapat di Wangi-Wangi Selatan disebabkan oleh semakin tinggi jumlah penduduk, kebutuhan akan sumberdaya semakin tinggi, sehingga interaksi dengan sumberdaya alam semakin tinggi yang akan menyebabkan tingkat persaingan untuk memperoleh sumberdaya laut. Nelayan Suku Bajo yang terdapat di Kecamatan WangiWangi Selatan yang sering menangkap ikan di "Karang" tidak lagi melakukan upacara pembuka laut, padahal ritual ini dilakukan untuk meminta ijin kepada "Mbo Madilao" atau penguasa laut di daerah perlindungan laut. Menurut Baharudin (2011) hilangnya pola perlindungan sumberdaya laut mengindikasikan bahwa saat ini terjadi batasan dalam kegiatan pemanfaatan sumberdaya laut, yang berarti intesitas pemanfaatan nantinya akan tergolong tinggi, sehingga ancaman kerusakan akan tinggi.

Pada dasarnya kearifan lokal bisa mengakomodir dan bisa sejalan dengan tujuan dari kawasan konservasi itu sendiri dengan tujuan melindungi suatu kawasan dan biota dari kawasan itu sendiri. Akan tetapi di lapangan maksud dari tujuan konservasi itu sendiri sangat sulit dipahami oleh nelayan masyarakat Suku Bajo karena menggunakan bahasa ilmiah yang benar-benar sangat sulit untuk mereka pahami.

\section{SIMPULAN DAN SARAN}

\section{Simpulan}

Kearifan Lokal Suku Bajo masih memegang peranan penting dalam pengelolaan kawasan konservasi seperti: tuba dikatutuang yang merupakan larangan penangkapan dalam jumlah besar di area ini dan penggunaan alat tangkap yang tidak ramah lingkungan. Parika merupakan sistem kelembagaan bertindak sebagai penentu waktu penangkapan dan pada tempat penangkapan, adanya situs keramat yaitu karang tapotong dan lua angalo juga masuk dalam daerah 
perlindungan laut merupakan upaya konservasi lokal melalui pengkramatan suatu tempat. Kesadaran konservasi nelayan Suku Bajo tercermin dari bagaimana cara mereka dalam mengelola laut dengan Teknik menangkap ikan laut secara tradisional suku Bajo antara lain: Memanah ikan, menjaring ikan, pancing dasar, menyuluh dan meti-meti.

\section{Saran}

Saran hasil penelitian selanjutnya adalah: (1) Perlu adanya penguatan sanksi-sanksi adat, sosialisasi danyuluhan tentang pengelolaan kawasan konservasi tentunya kearifan lokal Suku Bajo sebagai media untuk kegiatan tersebut; (2) nilai-nilai kearifan lokal lebih dipekuat lagi untuk menjaga kondisi ekologi di Taman Nasional Wakatobi; (3) Untuk mengurangi tekanan terhadap sumberdaya ikan perlu adanya peningkatan keterampilan sebagai pemandu wisata khususnya yang tinggal di daerah pusat wisata;

\section{DAFTAR PUSTAKA}

Kemenhut. 2012. Informasi Taman Nasioanal Laut. Pola Grade. Jakarta

Baharudin, S. 2011. Pergeseran Nilai Tradisional Suku Bajo Dalam Perlindungan dan Pemanfaatan Sumberdaya Laut Taman Nasional Wakatobi. IPB. Bogor
Coremap. 2009. Monitoring Kondisi Terumbu Karang Di DPL Program Coremap II Wakatobi Tahun 2009 (t-1). Coremap II Wakatobi. Wakatobi

Hanan. 2010. Kajian Strategi Pengelolaan Sumberdaya Laut Oleh Masyarakat Adat Dalam Kawasan Taman Nasional Wakatobi. IPB. Bogor

Royyani. 2012. Hutan Keramat Dan Strategi Konservasi di Rangkas Bitung. Jakarta

Saad, Sudirman. 2009. Bajo Berumah di Laut Nusantara. Coremap II. Jakarta

Sartini. 2009. Ritual Bahari Di Indonesia: Antara Kearifan Lokal Dan Aspek Konservasi. UGM. Djodjakarta 